\title{
DEMYSTIFYING THE PERSPECTIVES OF SCHOOL PRINCIPALS AS LEADERS OF CURRICULUM CHANGE: THE CASE OF INDONESIA
}

\author{
Munifah \\ Faculty of Tarbiyah, State Institute of Islam, Kediri, East Java, Indonesia \\ munifahkediri@gmail.com
}

\begin{abstract}
Whenever there is a policy of applying a new curriculum, there is always support and opposition, and so too did this happen when the 2013 Curriculum (K13) was applied in Indonesia. All this time the success of the application of a new curriculum has only been linked with the role of the teacher as the in-class executor; not many have focused on the role of the principal as a leader, and yet the principal plays a role in coordinating, helping, motivating, supervising, and evaluating the implementation of the curriculum so that it succeeds as expected. This research is aimed to understand the perspective of the principal toward curriculum changes in Indonesia and effective leadership during a curriculum change. This research used a qualitative approach as a study phenomenological case study through interviews with several principals at various education levels that have applied the K13. This research was conducted in East Java as a region that can be considered as a representation of Indonesia. Research results show that principals supported the change in curriculum as long as the new curriculum is better, supports achievement of school visions and missions, and could be implemented. Conceptually, the K13 is already good, but its implementation has not been well because of the factors of lack of teacher preparation, limited facilities, as well as the low motivation and ability of the principal; these weakness factors may be alleviated through transformational leadership. Success in the change of a curriculum requires a time frame of two years, and as such the government does not need to create ever-changing policies of K13 application, because this instead burdens many parties, in particular the principal. Leadership in curriculum change can be effective should the principal possess consistency and mastery of the new curriculum concepts as well as their implementation.
\end{abstract}

Keywords: principal leadership, education supervision, curriculum change, 2013 curriculum

\section{INTRODUCTION}

Up to now, research on curriculum change has been more linked with the teachers and students as actors of education, and not linked with the principal as a leader of education that yang sets in motion and facilitates change. Even though the principal is not directly involved in changes in curriculum concepts, he or she however understands every problem present in a school and is the primary initiator in curriculum implementation (Gibson, Ivanchevich, Donnelly, 1985). Research results have showed that the principal becomes a victim when a curriculum reform occur (Walker, et al. 2011). The participation of the principal has a major effect on the success of the implementation of curriculum changes, including cases of curriculum changes in Indonesia which to this day has not yet been perfectly implemented. Changing curriculum policies have become one of the problems in education in Indonesia (other than problems of managerial weaknesses, slow development of teacher competence, low level of innovation, and lack of teacher commitment). Meanwhile, the many obstacles in curriculum change affect the firmness of the government in creating curriculum policies. As such, to realize the goal of educational reforms (in Indonesia) there needs to be improvement in principal leadership (Sofo, Fitzgerald, \& Jawas, 2012), as well as elevating the capacities of the principal and the school principal leadership team (Cravens \& Hallinger, 2012).

Execution of education reforms is indeed very complex and requires the participation of all parties. Execution of education reforms must consider the regional political conditions, differences among regional governments, schools, classes, and interests of stakeholders (Cravens \& Hallinger, 2012). Reforms in education requires decentralization that provides soft policies (Chan, 2012), permits regional governments to make decisions for their own regions (Germeten, 2011), and gives the authority to determine the policy standard according to the real conditions in the field (Qian \& Walker, 2013). On the other hand, the principal was judged to be a barrier in Education for Sustainable Development (ESD) in Cypriots USA because of a lack of confidence, not wanting to challenge the status quo, a lack of involvement, and not being able to respond to standards of national education policies (Beltran, Zachariou \& Stevenson, 2013). The principal was also judged as the primary barrier in curriculum implementation in China because the competence of curriculum leadership was considered weak (Walker, Haiyan, Shuang, 2011). The quality of school leadership is the most important factor in achieving high-quality education results (Kaparou \& Bush, 2015).

The principal plays an important role in creating innovation and overcoming organizational problems (Luthans, 2005), The principal must understand situations and possess the art of influencing others (Hughes, 2012), become an agent of sustainable change, create effective policies and strategies to respond to incentives of change appropriately and intelligently (Wibowo, 2007), as well as to create a climate that encourages school members to participate and respond to changes constructively at the level of local and national policies (Sofo, Fitzgerald, \& Jawas, 2012). Principals are demanded to be able to condition curricula and learning situations in various ways. The school principal must become an instructional leader that is solid, cooperative, and directed (Salo et al., 2015). Principals possess many things to support his or her leadership (DeMatthews, 2014).

Principals in various countries have attempted to increase the quality of curriculum and learning in accordance with the problems and character of the 
region. In Africa, principals have a central position, in particular in ensuring coherence between curriculum and academic content in the learning process (Grobler, 2013). In Greece, the findings showed that Instructional Leadership was conceptualized as an informal collaborative leadership practice, interwoven with the official multi-dimension role of Greek principals and their 'semi-Instructional Leadership' role (Kaparou \& Bush, 2015). In Australia, principals utilize external teams that master and are experts in curricula (Smeed \& Bourke, 2012). In Shanghai, principals conduct programs of teacher competence development in accordance with the standards of the new curriculum (Qian \&Walker, 2013).

From studies on the change in the 2013 Curriculum (K13) from July 14 - September 82014 in 142 schools in 21 provinces and 46 regents/cities, it was found that there were five primary problems in the execution of K13, which were distribution of textbooks, usage of School Operational Funds (BOS), book contents, printing, and teacher training. In the end the government delayed the application of K13 and returned to the Educational Units Curriculum (KTSP) of 2006 except for schools that became models (pilot projects). Then in 2016, implementation of K13 was left up to the preparedness of each school and it was targeted that in 2018 all schools in Indonesia has to have applied the 2013 Curriculum, yet up to today (nearly two years) K13 has not been fully applied in all schools. These changing curriculum policies have an implication on the burden of the task of the principal as an instructional leader, because when a change occurs in curriculum policies, the principal automatically has to perform changes related to the effectiveness of the learning situation, supervision of teachers, as well as communication and cooperation with the public.

Based on this background, this research is aimed to reveal the perspectives of principals toward curriculum changes in Indonesia as well as effective leadership for the implementation of a new curriculum through interviews with principals in various forms and levels of education present in East Java, Indonesia.
Next, the data is considered relative to the theory of transformational leadership, as leaders that are charismatic, inspirational, intellectually stimulating, and individually attentive (Wibowo, 2007). It is expected that the results of this research provides benefits for curriculum policy makers, composers of curricula, and executors of curriculum changes in Indonesia and other regions, as well as being beneficial for the development of an efficient and effective theory in curriculum change.

\section{Setting}

\section{METHODS}

This research was conducted in Indonesia, where there had just been a curriculum change into what is called the 2013 Curriculum (K13) but up to today has not been carried out in full. Since Indonesia gained independence on August 17, 1945, the education curriculum in Indonesia has undergone several changes: 1947 Learning Plan, 1950 Learning Plan, 1958 Learning Plan, 1964 Learning Plan, 1968 Learning Plan, 1975 Curriculum, 1984 Curriculum, 1994 Curriculum, 2004 Competence-Based Curriculum (KBK), 2006 Educational Units Curriculum (KTSP), and the latest curriculum being the 2013 Curriculum (K13).

Educational institutions in Indonesia are handled by two ministries, the Minister of Education in organizing general schooling as Elementary Schools (SD), Middle Schools (SMP), and High Schools (SMA) as well as Vocational Schools (SMK), and the Minister of Religion in organizing religious schooling as Madrasah Ibtidaiyah (MI), Madrasah Tsanawiyah (MTs), and Madrasah Aliyah (MA). These educational institutions exist as both public and private ones. In general, there are no substantial differences between public and private schools; the difference is more in asset ownership, the status of teaching staff, sources of funding, the management structure, and the decisionmaking process. The following is the data for private and public schools in Indonesia:

Table 1

Number of Schools in Indonesia in 2014

\begin{tabular}{|c|c|c|c|c|c|c|c|c|c|c|c|c|}
\hline \multicolumn{3}{|c|}{ Elementary (SD/MI) } & \multicolumn{3}{c|}{ Middle (SMP/MTs) } & \multicolumn{3}{c|}{ High (SMA/MA) } & \multicolumn{3}{c|}{ Vocational (SMK) } & \multirow{2}{*}{ Total } \\
\hline Public & Private & Total & Public & Private & Total & Public & Private & Total & Public & Private & Total & \\
\hline 134.235 & 38.506 & 172.741 & 23.675 & 30.674 & 54.349 & 6.996 & 13.616 & 20.612 & 3.243 & 9.127 & 12.370 & 260.072 \\
\hline
\end{tabular}

Even though there are more than 260 thousand schools in all, those that were established as executing schools for K13 numbered only to about 6310 schools. For elementary schools, the 2013 Curriculum was implemented in 2.598 schools, by 15.629 teachers, and 341.630 students. For middle schools, this was 1.521 schools, 27.403 teachers, and 342.712 students. For high schools, this was 1.270 schools, 5.979 teachers, and 335.940 students. Finally, for vocational schools, this was 1.021 schools, 7.102 teachers, and 514.783 students. The total of executors of the 2013 Curriculum was 6.410 schools, 56.113 teachers, and 1.535.065 students. The number of executing schools differed by regions. These regions were Aceh (132), Bali (203),
Central Java (881), West Java (887), East Java (1053), North Sumatera (263), Banten (225), Jogjakarta (146), and Jakarta (250).

\section{Research Approach}

This research is a qualitative research using the phenomenological approach which is intended to understand the meaning of events and interactions in their relation to people in certain situations (Bogdan and Biklen 1998). Data and facts were collected indepth from a natural setting with the expectation that this would result in a complete and holistic picture of the perspective of the principal as a leader of curriculum change in Indonesia". 


\section{Data and Data Sources}

Data or information that was traced in this research was data on the perspectives of principals toward current curriculum changes in Indonesia and on effective leadership of curriculum change. Data were collected from people who experienced the phenomenon through qualitative interview or face-toface interview (Creswell, 2014) with principals who have implemented policies of curriculum change as statements related to the research focus. Interviews were conducted two to three times (member check) for data validity testing each occurring for 30 minutes.
As suggested by Creswell (2013), the participants of a phenomenological research should number between 5 to 25 people who have experienced a phenomenon; as such, the participants in this research totaled 11 principals in East Java who had implemented the policy of curriculum change or are using the 2013 Curriculum (K13) from various levels of education by the Minister of Education (SD, SMP, SMA) and the Minister of Religion (MI, MTs, MA), both public and private schools, with the reason that the characteristics of East Java make it a microcosm of the various conditions of education in Indonesia.

Table 2

The Institution of Research Locations

\begin{tabular}{ccll}
\hline No. & Initial & \multicolumn{1}{c}{ Principal Name } & \multicolumn{1}{c}{ Institution } \\
\hline 1 & A1 & Abdul Basith & SMAN 6 Kota Kediri Jawa Timur \\
2 & B1 & Suryanto & MAN Mojoagung Jombang \\
3 & C1 & M. Masyhur Billah & SMPN 1 Pangarengan Sampang Madura \\
4 & D1 & Emi Tahmidah & MTsN Sumobito Jombang Jawa Timur \\
5 & E1 & Nurul Latifah & SDN Banjaran IV Kota Kediri \\
6 & A2 & Asmiyanto & SMA Hasyim Asyari Lamongan \\
7 & B2 & Mochamad khotib & MA Matholiul Anwar Lamongan \\
8 & D2 & Zainal arifin & MTs Karang Ploso Malang \\
9 & F2 & Meike Susana & MI Mambaul Ulum Kota Kediri \\
\hline
\end{tabular}

\section{Data Analysis}

Data that was collected from interview results were read and re-read, and then analyzed through scrutiny, reduction, explanation, and inductive conclusion. The process of data analysis was conducted for each subject along with the data collection process and after data collection was completed (Miles \& Huberman, 1992). The discussion is holistic in nature by developing the complete and thorough picture of the issue from various perspectives and complex relationships of the various factors from a situation, as well as to create a theme or sketch of the apparent big picture (Creswell, 2013).

\section{RESULTS AND DISCUSSION}

Leaders must possess a set of systems of moral values covering vision, empathy, consistency, and integrity to create trust among followers (Hughes, 2012). A strong leadership is very important to achieve school success in performing a curriculum change. A principal is demanded to able to create a strategic vision and effective planning as solutions that will enable schools to continue to progress. Principals need to prepare themselves maximally because they will experience various issues in elevating school status, increasing teachers, personal leadership, building positive relationships with all parties, and managing crisis (Okoko, Scott \& Scott, 2015). Unification and empowerment of school resources need to be conducted appropriately and proportionally. Leaders must be able to gauge between rational and emotional considerations when affecting others (Hughes, 2012). Leaders must be able to set in motion possessed human resources in order to progress to achieve the goals of change (Smeed \& Bourke, 2012). Leaders need to build personal credibility and affect other people by creating skills and trust or relationships with co- workers (Hughes, 2012). Principals must apply a leadership approach that combines stakeholders from various fields of knowledge (DeMatthews, 2014) and be able to make use of a team of education and technology experts in everyday leadership practices (Reyes, 2015).

\section{The Principal is the Leader of Curriculum Change}

According to the perspective of the principal, the success of a curriculum change depends on how the principal responds to the policy and moves his or her members. Principals who are responsive will immediately move all possessed resources by the school and the school community will also execute the policy (A1). In contrast, passive principals instead will also make the school community also passive toward the curriculum change policy (B1). Leading change is one of the most important and difficult leadership responsibilities. Effective leadership will be able to renew organization and facilitate adaptation toward a changing environment (Yukl, 2010). The important task of an organization leader is to aid in establishing realistic expectations, show patience, ensure that employees will obtain new skills, and build programs of practice and guidance (Hughes, 2012). There are four stages in implementing change: opening minds, giving reasons before offering change; winning hearts, showing emotions through appreciation, care, and communication; enabling actions, communicating and affirming that subordinates understand the rationality, purpose, and benefits of change; and rewarding achievement, appreciating subordinates and their contributions (Wibowo, 2007; Tan, 2002).

Principals feel burdened when receiving rejections from teachers, yet by not following regulations there is the fear of receiving penalties, and 
over time teachers will finally become wellconditioned (B2). Any change will surely face resistance (Wibowo, 2007). There needs to be enough time to prove the benefits of change because when employees learn new things there often occurs an expectation-performance gap that creates frustration leading to lowered performance and rejection (Hughes, 2012). According to Kreitner and Kinicki, there are eight factors of organizational resistance toward change, which are an individual's predisposition toward change, surprise and fear of the unknown, climate of mistrust, fear of failure, loss of status and/or job security, peer pressure, disruption of cultural tradition and/or group relationship, personality conflict, lack of tact and/or poor timing, non-reinforcing reward system (Wibowo, 2007). There are four reasons why people do not wish to change, which are not knowing what must be done, how to do it, why it must be done, and what obstacles are beyond control (Wibowo, 2007; Tan 2002). Here the task of a leader is to affect the group by understanding, urging, inviting, guiding, moving, directing, and aiding until the goal of change succeeds.

Culture affects work achievement strongly (Kotter \& Heskett, 1997). Work culture must shift from complaining and whining, double standards, waiting for signs, and being afraid of making initiatives, to a formula that stresses initiative, confidence, and autonomy under the umbrella of organization management. Owens (1987) states that the behavior of individuals affects the group behavior, which automatically will affect the behavior of the system. Next, this behavior will develop where there is trust, based on integrity, competence, consistency, loyalty, and openness; subtlety, or something refined in relationships and acts as a social adhesive; and intimacy, or togetherness among organization members with a shared understanding of the value of an organization (Ouchi, 1981). This means attitude, personality, perception, and motivation of each teacher toward curriculum change will affect other teachers and affect the entire work system, and thus the principal is demanded to be able to affect and move the teachers to implement the new curriculum in order to achieve the vision and mission of the school.

\section{Curriculum is a Unity of Concept and Implementation}

A concept or decision has to be implemented effectively. A decision or concept that is not implemented is nothing more than pure abstraction. Conceptually, the 2013 Curriculum (K13) is better than the previous curriculum (KTSP); among the advantages of the K13 are a clearer embedding of spiritual and social values (A1), a more practical and concrete scientific approach and more emphasis on high-level competence and not just memorization (D1), and clearer links with achievement of the school vision and mission (B1). Even so, because of several factors, the concept of a good curriculum becomes less meaningful where its implementation is not as good as its concept. Among the factors that hinder the implementation of the 2013 Curriculum are the lack of understanding and ability of the teachers to use the K13 (A1), an evaluation system that puts too much burden on teachers (D1), supporting facilities that are not ready (B1), and that which makes executors of the curriculum on the field stuck on pure formality (C1).

According to Ronald C. Doll as quoted by Peter F. Oliva (1992), curriculum is the "formal and informal content and process by which learners gain knowledge and understanding, develop skill, and alter attitudes, appreciations, and values under the auspices of that school". Curriculum is a unity among learning concept contents and acts of teaching and learning; both are inseparable. The quality of a curriculum is evaluated from the resulting concepts and concepts that are implemented. When the implementation of a curriculum has not been suitable with what is conceived, this basically means the curriculum has not been realized. Good decisions or concepts will be destroyed due to bad implementations (Gibson, Gibson, Ivanchevich, Donnelly, 1985). Implementation of the $\mathrm{K} 13$ is still fixed on formality, not yet on substance, because teachers as the frontline actors have not yet obtained adequate K13socialization and training, and the required learning facilities have also not been adequate. Principals find teachers who face practical problems on the field, and as such the principal is demanded to act more flexibly and adaptively as well as possess a more innovative solution for the implementation of the curriculum concepts so that effective learning may be realized (Kaparou \& Bush, 2015). A principal is able to condition the implementation of the 2013 curriculum as good as its concept after a progress of two years when several of the obstacles have been minimized.

\section{Curriculum Change Requires Planning and Sufficient Preparations}

Fundamentally principals in Indonesia agree that there must be a change of curriculum to improve the learning outcome of students. A good-quality change of curriculum can help principals accelerate the achievement of the vision, mission, and objectives of the school (D1). The objectives of a change of curriculum will be achieved if the process of curriculum change contains improvements, is conducted in time, has clear goals and direction, and involves various parties. The 2013 Curriculum has drastic and hurried changes, leaving many schools unprepared, in particular teachers and students (B1), yet the change in curriculum will be effective should the apparatuses of implementation are prepared, in particular teachers and students as primary actors. As such, teacher socialization and training activities on things related to $\mathrm{K} 13$ need to be maximized. Curriculum changes also require preparedness of physical resources (C2), facilities, books, and learning media; when learning activities are not supported by sufficient facilities, then efficiency and effectiveness of learning is hard to realize.

Curriculum change must be performed in time, by adjusting to the needs of the stakeholders, development of science and technology, the need of a new curriculum, and when human and physical 
resources are prepared. As such, a change of curriculum needs to be thoroughly planned by these principles: (1) based on rational and objective beliefs as well as concrete data; (2) accurate analysis of data and facts so that this may result in a convincing estimate as well as a standard of supervision; (3) sustainability from the existing curriculum and not from scratch; (4) flexibility and responsiveness toward the demands of the people and easy execution; (5) any possessed strength and basic capital that are collected, coordinated, and efficiently utilized for increasing effectiveness; (6) reliance on one's own strength and not on the strength of another party, which may not be clear; and (7) coverage of the entirety of essential aspects that are related and composed scientifically and systematically.

Public participation as participatory planning provides a strategic value and substantive advantages in the form of public support and satisfaction (Sinambela, 2014). Principals need to take a more practical approach and to work more collaboratively with teachers (Qian \& Walker, 2013), and the two must always improve on practices that have been conducted (Grobler, 2013). This means a curriculum change should be planned by involving several parties, done completely and covering all the various aspects that are related to curricula, be prepared more thoroughly from socialization, teacher training, to support facilities so that the implementation of curriculum change succeeds. The quality of school planning and preparation in implementing curriculum changes affects the speed of curriculum achievement.

\section{Implementation of a Curriculum Change Requires Soft and Consistent Policies}

Principals are dazed and confused in facing changing policies of curriculum change. Lack of clarity in regulations causes confusion and desperation, and doubt and misunderstanding, burdening the tasks of the principal, and making them inefficient $(\mathrm{C} 1)$. As a leader of education, the principal needs support from policies that are clear and consistent in concept and implementation so that executors in the field can ensure the steps to be taken (A1); for principals it is easier to perfect the preparations of a new curriculum rather than to return to the old curriculum. According to Yukl $(2010 ; 346)$, too many changes in a short time can reduce commitment, as is the case in China where principals have not applied changes in the curriculum according to policies because of the factor of ambiguous government messages (Walker, Haiyan, Shuang, 2011). "Upgrading" the curricular leadership of a principal is indeed important, but what is more important is how the government clarifies the policies given to the principal and can be consistent with them.

School conditions and preparedness for applying the new curriculum differ from one to another, so this also needs differing treatment (D2). To accommodate differences in school preparedness in responding to curriculum change, there needs to be soft policies (Chan, 2012), policies that support public interests (Sinambela, 2014), and decentralization that allows for a principal to make decisions and empower the school (Danim, 2010). A principal needs to give personal attention and trust to a teacher until they feel more comfortable with the curriculum change as well as to evaluate the teacher professional development program at the school (Qian \& Walker, 2013). When teachers are given confidence and the chance to develop themselves, then they can be more committed to their professional development, certainly within a consistent standard and control.

\section{Implementation of a Curriculum Change Requires Proportional Pressure}

Curriculum change in Indonesia is driven by weak learning processes, low student achievement, increasing demands of stakeholders, and the current political conditions (A1). The occurrence of changes is usually due to external pressures in the form of stakeholder, technology, and political urges, as well as internal pressures in the form of process obstacles and behavior of members in an organization (Gibson, Ivanchevich, Donnelly, 1985). Even so, if the pressures of time and preparedness demands are very high and burdensome, this may instead lead to fear and lower the motivation of executors to change, especially for teachers (E2). This means external pressures will positively influence change should the abilities of actors of change be sufficient. Conversely, pressures that are too great will have a negative impact because they are imbalanced to abilities. Even so, the effectiveness of curriculum change is not only through strength of pressures but also needs to be balanced with aid and cooperation.

The change to the 2013 Curriculum can be implemented quickly and appropriately should leaders be ready and able to respond to a variety of pressures (D1). Organization members must feel pressure from the people or forced government regulations so that they are ready to face changes (Winardi, 2007). Pressure or compulsion can be used by leaders to move employees to achieve expected targets (Wibowo, 2007). Executors of curriculum change assume that government pressure is more serious than pressure from other elements, as in the case of Australia receiving heavy pressure in the continuous increase of exam result standards from the government (Smeed \& Bourke, 2012), Hong Kong being threatened of lower budgets with reduced numbers of students (Chan, 2012), and South Africa being pressured to achieve National Exam standards (Grobler, 2013); as a result principals attempt to empower all available resources, becoming directly involved in the learning process. The implementation of a curriculum change requires proportional pressure as motivation as well as authority so that principals are able to coordinate and empower all resources. Too heavy of a pressure at the moment when resources are limited instead causes despair and creates ineffectiveness in curriculum change because implementation becomes not as good as the concept.

\section{Supervision Becomes an Important Element in the Implementation of Curriculum Change}

Basically, a person does not wish to change not only because of unwillingness, but may also be 
because of inability and not understanding how to carry out the change; as a result, a curriculum change needs to be followed up by supervision and provision of an environment conducive to learning. The unwillingness of teachers applying the $\mathrm{K} 13$ is because their understanding of K13 is not perfect and they still experience difficulty, so that the principal has the task of making teachers understand the importance of K13 by training, motivating, controlling, and facilitating them (D1). Principals need to monitor learning by teachers, provide examples of effective teaching, and facilitate learning and prevent learning time from being disturbed by other activities (Grobler, 2013).

All changes need time to prepare understanding and skills of implementation (A1). Meanwhile motivation, skills, instinct, aspiration levels, and personal factors such as age, education, and family background have a role in increasing performance (Ivancevich, 2005). Teachers will be in desperation and feel unfair when the weight of change being applied is not supported by good facilities, a comfortable work environment, and a guarantee of legal protection for the occupation (Yukl, 2010; 346). Because of this, socialization and training for teachers need to be maximized until they are fully prepared to implement K13 (E2). Principals motivate teachers to not be disappointed, to remain spirited, to stay prepared, and to develop their qualities (Danim, 2010), and to encourage development of teacher competence, recognize weaknesses, as well as to evaluate programs of teacher development that have been conducted (Qian \& Walker, 2013). Principals must be sure that instructional leadership directly affects the quality of teaching, and principals must convince teachers of the strong relationship between teaching and the results of learning.

Instructional leadership is complex and challenging. In an international context, though different by cultures and conditions, there is the equality that the practice of learning in the classroom and instructional leadership has an effect toward student learning (Kaparou \& Bush, 2015). Activities of instructional leadership cover development of school vision and missions; coordination, monitoring, and evaluation of the learning curriculum and creation of a learning environment that is safe and supportive for students; as well as to create a work environment that supports collaboration for teachers (DeMatthews, 2014). Principals will succeed in becoming leaders of learning when they are able to provide supervision, foster the confidence of teachers, become a critical friend, affirm the efforts of teachers, and possess competence of teaching, dedication, experiences of control, and skills in communication (Salo, Nylund, \& Stjernstrøm, 2015). In this case there needs to be a coaching approach to leadership that stresses on training and guidance in an environment of partner relations, has mutual trust, is appreciative, provides time for learning and freedom of expression, and reduces limits and controls, but still allows for systematic evaluation of results (Luthans, 2005). This means in the practice of instructional leadership, the principal can collaborate between a formal role and a semi-formal or informal role (Kaparou \& Bush, 2015).

\section{Involvement and Cooperation among Parties Need to be Maximized}

Among the factors that hinder the implementation of a curriculum in Indonesia is the lack of involvement of various parties in the process of curriculum change, making information on needs and field conditions as the basis for making decisions not perfectly accommodated (A1). Chan also concluded that the difficulty in reforming the curriculum occurs because teachers (in their professional capacity) are not given a chance to participate (Chan, 2012). According to Beckhard, in an organization that conducts changes there needs to be participation and involvement of people in re-learning their problems and practices so that they become committed towards change (Winardi, 2007). Because of this, principals need to speak about change with the people who would be most affected by the change so that they can learn about their worries and suggestions (Yukl, 2010).

The curriculum reform movement can succeed if the owners and organizers of schools at the city level can truly involve themselves in the curriculum implementation fully and professionally, not just solely the principal (Germeten, 2011). Teachers must be given room to move to make their own efforts in learning, which means that requirements that have been made on the application of the curriculum can be adjusted with the conditions that the teacher has attempted to provide (Qian \& Walker, 2013). The more an organization or someone becomes involved in the process of change, the greater the possibility of accepting that change becomes (Gibson, Ivanchevich, Donnelly, 1985). To drive the involvement and cooperation of teachers in the implementation of a new curriculum, principals need to possess effective communication skills, which are the abilities to send and receive information with a high probability, since the quality of communication of a leader has a positive relationship with subordinate satisfaction, productivity, and quality of service (Hughes, 2012).

\section{Curriculum Change is Affected by the Factor of Politics and Public Opinion}

The changing policies of the Indonesian government on the curriculum are also affected by pressures of political interests, social media attacks, and positive-negative perceptions of education analysts (A1). This implicates the reduction of teacher motivation and confidence so that implementations of curricula in Indonesia proceed slowly (D1), let alone the culture of some Indonesian people who feel more comfortable in the comfort zone (B2). Similarly, curriculum reforms also proceed slowly in China because of strong cultural norms as well as the expectations and accountability of the people (Walker, Haiyan, Shuang, 2011).

Indeed, implementations of changes need to consider various factors including the factors of local politics, differences in contexts, stakeholders (Cravens $\&$ Hallinger, 2012), gender, school type, affiliations of 
teacher associations, economic social status of students, and groups of regional languages, and so the principal needs to consider these variables (Grobler, 2013). Every change surely faces resistance and obstacles, and the strategy to overcome them is through education and communication, participation, facilitation, and support, negotiation, manipulation, and cooptation, as well as force or violence (Wibowo, 2007). As long as the new curriculum has become appropriate with curricular principles and supports the achievement of national education goals, then various strategies must be conducted to face various obstacles and external challenges.

\section{Principal Leadership Needs to be Continuously Developed}

Principals must possess knowledge of the 2013 Curriculum that is wider, deeper, and earlier than teachers (B2); master and understand every policy of education curricula and follow their development (D1), and be able to socialize these and impart their understanding to the members of the organization (B1). Because of this, principals need to be more excellent than subordinates; the principal must have three basic skills, which are conceptual skills of the curriculum, technical skills in applying the curriculum, and understanding and communication skills to move the actors of curriculum implementation (Winardi, 2007). The principal as the curriculum leader is demanded to keep learning and developing oneself (Gibson, Ivanchevich, Donnelly, 1985), through various training that is continuous, relevant, and directly affects the improvement of performance (Danim, 2010), through formal education and experience (Hughes, 2012), and by performing research on successful leaders and strategic organization maneuvers, (Luthans, 2005), in order to always succeed in facing reform policies (Cravens \& Hallinger, 2012).

In addition, principals must also possess charisma; obtain respect as well as trust, become an inspiration for its members; possess intellectual stimulation by showing intelligence, reason, and careful problem solving, and possess attention of personality by treating employees individually, training, and advising based on organizational values and culture (Luthans, 2005). To produce an effective leadership, principals need to continuously study various theories of leadership, consider and select those most relevant with the situation, and be able to apply leadership in various situations. (DeMatthews, 2014).

\section{CONCLUSIONS AND IMPLICATIONS}

The success of an implementation of a curriculum change requires quite a long time to be realized, since the effectiveness of the process and output cannot be seen directly. Fundamentally, educational institutions need curriculum changes on the macro level, school level, and micro level. Principals agree on changes to the curriculum as long as they are concrete, improve the new curriculum, support achievement of school vision and missions, and be in time with school needs, prepared human resources, and availability of facilities. Policies on curriculum change must be planned out well, clearly, and consistently, and there must also be an intelligent and strategic response from the principal, because all of these affects the efficiency and effectiveness of the achievement of curricular goals.

A curriculum represents the unity of learning concepts and their implementation. The quality of a curriculum is judged by examining their concepts and implementation. No matter how good is the resulting curriculum concept, if its implementation is not as good as its concept, then the results will not be appropriate with the purpose. A good concept needs to be followed up by the availability of supporting facilities and the preparedness of learning actors. Supervision is the most important tool for the success of the implementation of a curriculum change. Principals need to guide and aid teachers through various training; including them in facing curriculum changes; affecting and coordinating teachers and related parties; provide understanding to teachers, parents, and students; and provide facilities and infrastructure.

In addition to supervision as a primary tool, the implementation of a curriculum change also requires several technical tools including: (1) soft policies that support school conditions and interests, (2) pressure and target from power and the people, (3) socialization and argumentation that are objective and proportional, (4) training and education from expert teams in their fields, and (5) fulfillment of supporting adequate facilities for the implementation of the curriculum change.

Differences in perspectives of principals as leaders of curriculum change originates from differences in preparedness of school resources and motivation and commitment toward curriculum improvement. A curriculum change will succeed to its implementation if the principal understands well the concept and implementation of the new curriculum and has a high commitment in facilitating all needs for the execution. As such, the leadership of a principal needs to be continuously developed through various research, training, and education to increase success of tasks and responsibilities as a leader and supervisor.

\section{REFERENCES}

[1] Beltran, C. K., Zachariou, A., \& Stevenson, R. B. 2013. Leading Sustainable Schools: Exploring the Role of Primary School Principals. Environmental Education Research, 19:3, 303-323.

[2] Bogdan, R. C., \& Biklen, S. K. 1982. Qualitative Research for Education: An Introduction to Theory and Methods. Boston: Allyn \& Bacon, Inc.

[3] Chan, J. K. S. 2012. Curriculum Policy Implementation: How Schools Respond to Government's 'Soft' Policy in the Curriculum Reform. The Curriculum Journal, 23:3, 371-386.

[4] Cravens, X. C., \& Hallinger, P. 2012. School Leadership and Change in East Asia: Building Capacity for Education Reform. Peabody Journal of Education, 87:2, 157-161,

[5] Creswell, J. W. 2014. Research Design: Qualitative, Quantitative, and Mixed Methods. Approaches. Fourth edition. London: Sage. 
[6] Creswell, J. W. 2013. Qualitative Inquiry and Research Design: Choosing Among Five Aproach. Third edition. London: Sage.

[7] Danim, S. 2010. Otonomi Manajemen Sekolah. Bandung: Alfabeta.

[8] DeMatthews, D. E. 2014. How to Improve Curriculum Leadership: Integrating Leadership Theory and Management Strategies, The Clearing House: A Journal of Educational Strategies, Issues and Ideas, 87(5), 192-196.

[9] Germeten, S. 2011. The New National Curriculum in Norway: A Change in the Role of the Principals? Australian Journal of Education, 55(1), 14-23.

[10] Gibson, J. L., Ivanchevich, J. M., Donnelly, J. H. 1985. Organizations, Behavior, Structure, Processes. Texas: Business Publications, Inc.

[11] Glickman, C. D., Gordon, S. P., Rose-Gordon, J. M. 2004. Supervision and Instructional Leadership: A Developmenttal Approach, Sixth Edition. New York: Allyn and Bacon.

[12] Grobler, B. 2013. The School Principal as Instructional Leader: A Structural Equation Model, Education as Change, Volume 17, No. S1, 2013, pp. S177-S199. University of Johannesburg.

[13] Hughes, R. L, Ginnet, R. C, \& Curpy, G. J. 2012. Leadership: Enhancing the Lessons of Experience. 7th $e d$. New York: McGraw-Hill Education.

[14] Ivancevich, J. M. 2005. Perilaku dan Manajemen Organisasi. Jakarta: Erlangga.

[15] Kaparou, M., \& Bush, T. 2015. Instructional Leadership in Centralised Systems: Evidence from Greek High-Performing Secondary Schools. School Leadership \& Management: Formerly School Organisation, 35(3), 321-345.

[16] Kotter, J. P., \& Heskett, J. L. 1992. Dampak Budaya Perusahaan terhadap Kinerja. Jakarta: Prenhallindo.

[17] Luthans, F. 2005. Organizational Behavior. New York: McGraw-Hill Companies, Inc.

[18] Miles, M. B., \& Huberman, A. M. 1992. Analisa Data Kualitatif. Jakarta: Universitas Indonesia.

[19] Okoko, J. M., Scott, S., \& Scott, D. E. 2015. Perceptions of School Leaders in Nairobi about their Leadership Preparation and Development. International Journal of Leadership in Education: Theory and Practice, 18:3, 279-304.

[20] Owens, R. G. 1987. Organizational Behavior in Education. New Jersey: Prentice- Hall. Inc.

[21] Ouchi, W. G. 1981. Teory Z. New York: AddisonWesley.

[22] Oliva, P.F. 1992. Developing of Curriculum. New York: Allyn \& Bacon, Inc.

[23] Qian, H., \& Walker, A. 2013. How Principals Promote and Understand Teacher Development under Curriculum Reform in China. Asia-Pacific Journal of Teacher Education, 41(3), 304-315.

[24] Reyes, V.C. 2015. How do School Leaders Navigate ICT Educational Reform? Policy Learning Narratives from a Singapore Context. International Journal of Leadership in Education: Theory and Practice, 365385.

[25] Sagala, S. 2010. Supervisi Pembelajaran dalam Profesi Pendidikan. Bandung: Alfabeta.

[26] Salo, P., Nylund, J., and Stjernstrøm, E. 2015. On the Practice Architectures of Instructional Leadership. Educational Management Administration \& Leadership, 43(4), 490-506.

[27] Scott, C. D. 2010. Visi, Nilai, dan Misi Organisasi: Membangun Organisasi Masa Depan. Jakarta: Indeks.
[28] Sinambela. L. P. 2014. Reformasi Pelayanan Publik: Teori, Kebijakan, dan Implementasi. Jakarta: Bumi Aksara.

[29] Smeed, J. \& Bourke, T. 2012. Teachers' Perceptions of the use of an External Change Agent in School Curriculum Change. Aust. Educ. Res, 39, 207-220.

[30] Sofo, F., Fitzgerald, F., \& Jawas, U. 2012. Instructional Leadership in Indonesian School Reform: Overcoming the Problems to Move Forward. School Leadership \& Management, Formerly School Organisation, 32(5), 503-522.

[31] Walker, A., Haiyan, Q., Shuang, Z. 2011. Secondary School Principals in Curriculum Reform: Victims or Accomplices? Research Article Front. Educ. China, 6(3): 388-403.

[32] Wibowo. 2007. Manajemen Perubahan Edisi Kedua. Jakarta: Raja Grafindo Persada.

[33] Winardi. 2007. Motivasi dan Pemotivasian dalam Manajemen. Jakarta: Raja GrafindoPersada.

[34] Yukl, G. 2010. Leadership in Organizations. New Jersey: Pearson Education, Inc. 